\title{
A CASE STUDY OF LADAKHI VERSION OF GESAR EPIC: ITS INFLUENCE ON RELIGION, FOLKLORE, CULTURAL AND SOCIAL LIFE IN LADAKH
}

\begin{abstract}
In its Ladakhi version, Gesar Saga has come down through centuries orally, with storytellers reciting the epic orally. The oral versions from Ladakh were among the first to receive academic attention through the works of August Francke at the turn of the century, however most subsequent work has been on the Eastern Tibetan and the Mongolian Version of the Gesar epic. The Ladakhi version of the epic is relatively free from the strong Buddhist influence. The versions of this tradition vary from village to village. The paper examines the influence of the Gesar epic on folklore, cultural, and social life in Ladakh. The paper further analyses the Ladakhi version of the Gesar epic and its relationship with the pre-Buddhist Bon religion of Ladakh. It further examines how the epic tradition has permeated into Ladakh society by examining Ladakhi folk songs and festivals and looks at how the narratives of Gesar epic exhibit in the socio-cultural traditions of Ladakh.
\end{abstract}

Keywords: Kesar, Bon, Ladakh, glu, lha

The epic story of rGyalam Kesar remains the most popular folk story in Ladakh and its protagonist, Kesar in perhaps the most famous personality in Ladakhi culture. The Ladakhi version of the Kesar epic provides us glimpses of the soul of the Ladakhi people before Buddhism transformed it. In spite of the Ladakhi versions of the epic presenting a world rather different from that of the later Bon religion, the epic give us valuable sidelights into the primitive culture and history of the Ladakh. The rich traditions of folk literature in Ladakh and Baltistan are celebrated in festival, songs, hymns, fables and proverbs, dances, music and drama. Folk literature in the Indian Himalayas was greatly influenced by the literary traditions from Tibet and monastic and lay forms of Tibetan Buddhism. However the Ladakhi folksongs are also inspired by epic tales like Kesar of gLing, his wife Bruguma and Api Cho ${ }^{1}$. The remarkably diverse collection of Ladakhi folksongs $(\mathrm{glu})$ span over a period of more than a thousand years. These songs are classified on the basis of their purpose, social function or subject matter. These songs are sung in marriage (bag ston gyi glu), dance (shon glu), drinking (chang glu), archery (da glu); covering a wide range of occasions, topics and mood. Folksongs are the soul and body of Ladakhi folk literature (Akasoy, Burnett, and Tlaim 2016: 223-234).

\subsection{Kesar epic and pre-Buddhist religion of Ladakh}

Long before Buddhism spread across Central Asia, Mongolia, Tibet, and Ladakh, the people of these regions followed an animistic belief system and worshipped various deities and celestial objects such as the sun and the moon. Even important mountain passes, rivers, lakes, and trees were objects of worship and reverence. This belief system is called Bonism, which is called Pon-Chos or Lha-Chos in Ladakh. Francke (1905-1941) has translated these words as 'Convention of Deities' or 'Deity Worship'. According to Francke, the Bon religion was originally a form of primitive shamanism - a belief in unseen powers which were either harmless or harmful for man, and which could be controlled by men through magical rites and incantations. From the epic stories of the King Kesar, and from popular songs collected in Ladakh by Francke, he attempted to deduce and describe a Bon pantheon, which he suggested represented the Bon god-world in its primitive form, unmixed by the notions of Lamaistic Buddhism. This is the reference to the Kesar of gLing, whom Francke believed to be the central figure of the religion.

In this context, Francke asserts that it may be permissible to assume that the kernel of much of what is found in the Bsgyur Bon, and the pantheon of the Ladakhi Kesar saga, together with certain ideas analogous to Indian Tantricism including the leaning towards sorcery and mysticism, are derived from primitive Bon religion.

Khan (2017), a well known Ladakhi historian and bureaucrat and an author of Purig version of the Kesar epic describes the cosmology of the epic noting that the cosmos is divided into three realms. According to him the universe comprised of three distinct realm or worlds. In Ladakhi, the upper realm is called Styang Jung Lha-Yul, which translates as the abode of the gods and is located in the sky. This realm was ruled by Wangbo rGyabjin. Kesar is the son of Lha Wangbo rGyabjin, the god-king who rules over the heavens that is called Styang Jung Lha-

\footnotetext{
${ }^{1}$ Api Cho was believed to have been one of Old Baltistan's popular heroes living in Shigar. According to the tradition Api Cho was killed at the hands of Kesar.
} 
Yul in Ladakhi. The word "gods" translates the Ladakhi Lha which itself refers to a wide range of spirits. Most often, the term is used to describe these spirits of the mountains, who are also seen to inhabit Stanglha, the top most world of a three-tired cosmos. However, gods may have left the mountains behind them, Lha's are domesticated and they are found at the summits of human habitations. There are Lha's of castles, monasteries, village, and household. Everywhere, Lha's can be found at the top and shrines are made, offerings left at these miniature mountaintops. These spirits are regularly honored and propitiated in ritual. They are seen as guardians and protectors of their particular territories.

The middle realm is called the Ber Chan-Yul, which translates, as the abode of the Chans. The Chan King Chantha Kargo rules this realm. According to the legends, Chans always appears yellow or ochre in colour. The lowest realm is called Yog Jung klu-Yul, which translates as the abode of the underworld spirits. This realm believed to be located below the surface of the earth and is ruled by the King of the klus, klu rGyal Tokpo. Even now in Ladakh one can find shrines to such local gods known as Lhatho: lha-tho and spirits of the earth of water known as Lhubang: klu-bang. Various places such as springs, rivers, fields and the soiling of his abode (Lhusa), he-she can be a victim of s'notpa ( falling sick). While Buddhist monasteries are called Gonpa (temple) in Ladakh, Pon-Chos shrines are called Lha-Khang i.e abode of the diety. These Lha-Khangs can be seen in many houses and among the barley fields in Ladakh for prayer and Lhatos for ceremonial offerings.

\subsection{Kesar and Ladakhi Kinship}

Kesar as a epic hero is well known throughout Ladakh. In the chronicles of Ladakh (La-dvags rgyal=rabs: 35.9-10: Francke 1914/1926) "there is a mention of the descendent of Kesar ruling Ladakh prior to the coming of Skyid-lde Nyi-ma-mgon". In Ladakh various versions of the Kesar saga are available from Chiktan in Kargil, Changthang, Nubra, Lower Ladakh. Vohra (1995), mentions about the "descendants of Kesar ruling Ladakh during pre- $11^{\text {th }}$ century period". According to him "there are legends of Wanla Cho and rGya-pa Cho ruling in Ladakh prior to the coming of Nyi-ma-mgon and it is said that it is they who invited the latter to settle in Ladakh. yGya-pa Cho had kinship ties to Kesar rGyalpo.” During my personal interview with Murup Namgyal, (a Ladakhi folk musician and composer who is known for his contributions for the revival of Ladakhi and Tibetan folk music tradition), confirmed the legend of rGya-pa Cho. rGyapa Cho lineage still exists today and his descendants are known in Ladakh as that of royal decent.

\subsection{Kesar epic and its influence on folklore, culture and social life in Ladakh}

Apart from the kinship representation of the Ladakhi rulers with Kesar, traditional Ladakhi folk songs are part of a long tradition going back to early pre-Buddhist Tibet. In the Ladakhi folk songs one can often find references to Kesar and the world view described in the Kesar epic.

One of such genres of Ladakhi folk songs which dates back to the pre-Buddhist era are known as gying lu, these songs are generally 'praise songs' sung in honor of the kings. These 'songs' draw upon the poetic imagery of the Kesar epic, and place the king at the center of the world order (Trewin 1995:95). However, the depiction of Kesar is not restricted to gying $l u$, but is used in zung lu as well. A number of themes in zhung lu and gying lu reflect various aspects of the Ladakhi worldview.

Kesar epic has played a very important role in the formation of Ladakhi folk songs. Such an influence can be noted in marriage songs and Ladakhi marriage rituals. There are two important songs sung during the marriage ceremonies in Ladakh that are explicitly related to the Kesar epic. The tho-glu (stone pile song) and nyopa glu (Door songs). These wedding songs portray an awareness of local gods of the household, fields, waters, etc. A part of the marriage ritual and accompanying songs involves the bride saying goodbye to her home deities, and the transfer of her allegiance to those of her husband (Ribbach 1985). This further reflects the pre-Buddhist or Bonpo worldview that situates people in a matrix of multiple realms; human, natural and supernatural, as evident in the cosmology depicted in the Kesar epic.

The Kesar epic has left a strong imprint on the popular poetry of Ladakh. A number of songs such as the ones mentioned above are sung throughout Ladakh. During the spring, a Kesar festival or Dha-trses is held in all the villages in Ladakh, and the male population exercises itself in archery, special songs called 'Ling lu' or glin glu are sung during this festival. These songs usually mention episodes from the epic of King Kesar. According to Namgyal, "archery has a special place in Ladakhi society. During this festival songs of Kesar ( $g$ ling lu) are sung across Ladakh. There are hundreds of Ladakhi folksongs dedicated to archery. The songs reaffirm the identification of the archer as the ideal man, fearless in war and feud and social in the domestic sphere. Ballads called ga-glu, sung in some villages of Ladakh while plowing fields, include verses that are attributed to the Kesar epic.

According to Namgyal, "archery has a special place in Ladakhi society. During this festival songs of Kesar (gling $l u$ ) are sung across Ladakh. There are hundred of Ladakhi folksongs dedicated to archery. Arrows also hold 
a special place in many rituals and customs. For instance, when a child is born, people greet the family with an arrow whose tip is wrapped with a white silken scarf (Khatag) called dadar. Arrows also plays a special role in Ladakhi marriages as the person accompanying the bride ( $r$ Nyatit $p a$ ) carries an arrow wrapped with khatags. In the epic of Kesar, whenever the hero goes for a war an arrow with a Khatag is kept on a high mountain as a symbol of victory". He further mentioned, "Ladakhi's learned the art of archery from the Kesar epic. In the songs from the epic there are many references to archery. One of the song describes three arrows of which the first one is white and will hit the enemy, the second one is red and will such the enemy's blood, and the third one is black and will kill the enemy. The song also specifies that an arrow is divided into three portions (chik sum) and specifies that its length must cover the distance between the bow and the archer's shoulder, the importance of the metal tip (digo) and hawk's feather (tha-nkar), and the paste made from Yak's horn (rus-pin) that is applied to the surface of an arrow. And it is believed that if one follows this method mentioned in the Kesar epic, the arrow will never miss its target".

The songs reaffirm the identification of the archer as the ideal man, fearless in war and feud and social in the domestic sphere. Ballads called ga-glu, sung in some villages of Ladakh while plowing fields, include verses that are attributed to the Kesar epic.

It is of a popular belief in Ladakh that "weaving and the loom are modeled on the mythical loom of Bruguma, the wife of King Kesar. Oral version of it claimed that when she weaves on row a year and that when she completes the fabric on her loom the world will come to an end" (Ahmed 2002:14).

Rituals and folk songs constitute the key aspects through Ladakhi tradition is witnessed. They occupy a important role in the present Ladakhi society. The similarities between these rituals and Kesar epic suggest a deep link between the Ladakhi culture and the pre-Buddhist religion of Ladakh depicted in the Kesar epic. The epic depicts Kesar as a hero, as priest, as a human being, and as a healer and the hero of the epic continue to hold an important role in the rituals and festivals of Ladakh.

\section{Bibliography}

Chatterji, S.K (1981), “Introduction — The Saga of King gesar. In: The Epic of Gesar”, vol.29, Thimpu.

Dargyay, Eva. K (1988), In Search for Gesar. In: Uebach \& Panglung, pg. 87-93.

David-Neel, Alexandra, and Lama Yongden (1933). The Superhuman Life of Gesar of Ling the Legendary Tibetan Hero, as Sung by the Bards of his Country. London: Rider and Co.

Damdinsuren, Ts (1961), Tibetan Version of Gesar Saga Chapter 1-111, Corpus Scriptorum Mongolorum 8, 1. Ulanbator.

Dinnerstein, Noe (2013), "Songs, Cultural Representation and Hybridity in Ladakh." Himalaya, The Journal of the Association for Nepal and Himalayan Studies, Vol 32, No.1,Article 16.

Denwood, Philip (2005), "Early Connections between Ladakh/Baltistan and Amdo/Kham.” In Bray, John (ed.) 2005

Ladakhi Histories. Brill Tibetan Studies Library Volume 9. Brill, Leiden/Boston.

Fitzherbert, Solomon George (2009), The Tibetan Gesar Epic as Oral Literature, Dotson et al. (eds.), Serindia Publications, Chicago.

FitzHerbert, Solomon George. "Constitutional Mythologies and Entangled Cultures in the Tibeto-Mongolian Gesar

Epic: The Motif of Gesar's Celestial Descent.” Journal of American Folklore 129.513 (2016): 297-326.

FitzHerbert, Solomon George. “An Early Tibetan Gesar bsang Text.” Archiv Orientální 84 (2016): 1-60.

Francke, A. H (1905-41), A Lower Ladakhi Version of the Kesar Saga. Calcutta, Published by the Royal Asiatic Society of Bengal.

Francke, A. h (1901), A ladakh Bon po Hymnal. Indian Antiquity. Vol 30. Greene, Thomas (1963), The Descent From

Heaven, A Study in Epic Continuity, New

Herrmann, Silke (1991), Versions of the Gesar epic from Ladakh. Asiatische Forschungen Band.

Honko, Lauri (1990), Religion, Myth and Folklore in the Worls's Epics: The Kalevala and its Predecessors, Walter de Gruyter, 1990. Pg. 471-484.

Karmay, Samten. "Gesar: the Epic Tradition of the Tibetan People." Bulletin of the Department of Sanskrit and Indian Studies, Harvard University 2.3 (1992): 25-30.

Karmay, Samten. "The Theoretical Basis of the Tibetan Epic, with Reference to a 'Chronological Order' of Gesar's life

by aggregating various versions of the epic." Bulletin of the School of Oriental and African Studies 55.2 (1993): 234-246.

Kornman, Robin, Sangye Khandro, and Lama Chonam (2010) trans. The Epic of Gesar of Ling: Gesar's Magical Birth,

Early Years and Coronation as King. Boston: Shambhala.

Kornman, Robin (1995), A Comparative Study of a Buddhist Version of the Epic of Gesar of Ling, PhD Dissertation, Princeton University.

Kornman, Robin (1997), Gesar of Ling. In: Lopez

Korman, Robin (2005), "The Influence of the Epic of Gesar on Chogyam Trungpa." In: Midal, Fabrice. Recalling Chogyam Trungpa. Boston, Massachusetts: Shambala Publications. Pp. 347-379. 